\title{
ENTEROBACTERIA ISOLATION IN BROILER CARCASSES FROM COMMERCIAL ESTABLISHMENTS IN FORTALEZA, CEARÁ STATE, BRAZIL
}

\author{
W.M. Cardoso ${ }^{1}$, W.F. de Oliveira ${ }^{2}$, J.M. Romao', F.A.C. Sampaio ${ }^{1}$, T.G.V. Moraes ${ }^{1}$, \\ R.S.C. Teixeira ${ }^{1}$, S.R.Câmara ${ }^{1}$, R.P.R. Salles ${ }^{1}$, A.A. de Siqueira ${ }^{1}$, G.C. Nogueira ${ }^{1}$
}

${ }^{1}$ Universidade Estadual do Ceará, Faculdade de Veterinária, Laboratório de Estudos Ornitológicos, Av. Paranjana, 1700, CEP 60740-903, Fortaleza, CE, Brasil. E-mail: william.maciel@uol.com.br

\section{ABSTRACT}

Processing of poultry products requires a severe microbiological quality control, considering they are one of the main sources of foodborne infections. The objective of this research was to perform the isolation of enterobacteria in broiler carcasses from commercial establishments in the Metropolitan Region of Fortaleza in Ceará State, Brazil. Broiler carcasses were collected and selected as fresh $(n=14)$, refrigerated $(n=18)$ and frozen $(n=19)$. Carcasses were submitted to a rinsing method, followed by pre-enrichment and enrichment with Rappaport-Vassiliadis and Selenite-Cystine, streaked on plates with Brilliant Green, MacConkey and Salmonella-Shigella agars, and to a presumptive biochemical identification. It was verified that all broiler carcasses categories presented enterobacteria contamination, with the following frequency of isolation: Proteus sp., 66.7\%; Enterobacter sp., 15.7\%; Citrobacter sp., 2\%; Escherichia coli, 47.1\%; Klebsiella sp., $11.8 \%$; Shigella sp., $5.9 \%$, and Salmonella sp. $11.8 \%$. It was observed that no combination of culture media was able to detect all enterobacteria contamination in the broiler carcasses. Thus, it may be necessary the use of several combinations of culture media to determine the real microbiological quality of broiler carcasses.

KEY WORDS: Enterobacteria, broiler carcass, culture media, microbiological quality, Salmonella, methodology.

\section{RESUMO}

ISOLAMENTO DE ENTEROBACTÉRIAS EM CARCAÇAS DE FRANGOS DE CORTE PROCEDENTES DE PONTOS COMERCIAIS DE FORTALEZA, ESTADO DO CEARÁ, BRASIL. A carne de frango requer um rígido controle de qualidade microbiológica em seu processamento, uma vez que é uma das principais fontes de infecção alimentar para o homem. Desta forma, a presente pesquisa teve como objetivo realizar o isolamento de enterobactérias em carcaças de frango de corte obtidas em estabelecimentos comerciais na região metropolitana de Fortaleza no Estado do Ceará, Brasil. As carcaças foram coletadas e agrupadas em três categorias: frescas $(\mathrm{n}=14)$, refrigeradas $(n=18)$ e congeladas $(n=19)$. As amostras foram submetidas a um método de enxaguadura, seguido por pré-eriquecimento e enriquecimento seletivo com os meios RappaportVassiliadis e Selenito-Cistina, plaqueamento nos meios sólidos Verde Brilhante, MacConkey e Salmonella-Shigella e, posteriormente, a provas bioquímicas de identificação. Foram realizadas diversas combinações entre os meios para o processamento das amostras. Todas as categorias de carcaças apresentaram contaminação por enterobactérias, com as seguintes freqüências de isolamentos: Proteus sp., 66,7\%; Enterobacter sp., 15,7\%; Citrobacter sp., 2\%; Escherichia coli, 47,1\%; Klebsiella sp., 11,8\%; Shigella sp., 5,9\% e Salmonella sp., 11,8\%. Nenhuma combinação dos meios de cultura empregados foi capaz de isolar todas as contaminações por enterobactérias nas carcaças. Desta forma, é necessário o uso de várias combinações de meios de cultura para determinação real da qualidade microbiológica de carcaças de frango.

PALAVRAS-CHAVE: Fnterobactérias, carcaça de frango, meios de cultura, qualidade microbiológica, Salmonella, metodologia.

\footnotetext{
${ }^{2}$ Instituto Brasileiro do Meio Ambiente e dos Recursos Naturais Renováveis, Brasília, DF, Brasil.
} 


\section{INTRODUCTION}

Microbial food safety is an increasing public health concern worldwide. It is estimated that each year in the United States there are approximately 76 million food-borne illnesses (MEAD et al., 1999).

Broilermeatconsumptionisknownasoneof themain sources of food-borneinfectionsinhumans (FITZGERALDet al.,2001).Processing of poultry productsrequires asevere microbiological quality control, considering that they are the most accessible protein sources.

The level of Enterobactereaceae in poultry carcasses can be routinely used as an indicator of improper hygiene methods during processing and incorrect storage conditions, which canlead to the proliferation of pathogens, such asSalmonella, and toxin production (ROBERTS et al., 1995). Most enterobacteria inhabit human and animal intestines as members of their normal microbiota or as infectious agents (Trabulsi; CAMPOS, 2002). Contamination control during slaughter and processing has been identified as an ultimate requirement in order to detect the prevalence of pathogenic microorganisms in poultry products. Microbiological status of broiler carcasses depends on several factors, such as: infection level of living birds, cross contamination, amount and variety of pathogens, among others (ABU-RUwAIDA et al., 1994).

Despitecarefulpracticesperformedduring processing, carcasses may become contaminated with feces. Approximately $0.8-5 \%$ of the broiler chickens processed in the USA and Canada must be reprocessed or trimmed duetocontamination or disease (RUSSELL; WALKER,1997).

Campylobacter, Salmonella, and pathogenic E. coli can colonize the gastrointestinal tracts of a wide range of wild and domestic animals, especially animals raised for human consumption (Meng; Doyle, 1998).

Buzby (2002)reported that theoccurrenceof Salmonella infection in Americans over 60 years old was 10.8 cases per 100,000 and 17.4 per 100,000 at all ages. NADVORNY et al. (2004) found that broiler meat was responsible for $11.4 \%$ of food-borne diseases outbreaks in 2000 in Rio Grande doSulState.Since 1993, salmonellosis has been considered the major cause of illness and between 1987 and 2000, Salmonella was the cause of $34.1 \%$ of all outbreaks investigated in the same state.

The objective of this research was to evaluate the isolation of enterobacteria in broiler carcasses from commercial establishments in the Metropolitan Region of Fortaleza in Ceara State, Brazil.

\section{MATERIAL AND METHODS}

Broiler carcasses were collected from sales points and processing plants, and were selected into three categories: fresh carcasses (14 samples), collected in two processing plants with no federal sanitary inspection (7 carcasses in each plant); refrigerated carcasses (18 samples), ten in one supermarket and eight in another; and frozen carcasses (19 samples), ten samples collected in one supermarket, and nine from another.

The microbiological procedure for enterobacteria presumptive identification started with the samples submission to a rinsing method, reported by Cox et al. (1978), performed with the addition of $300 \mathrm{~mL}$ of buffered peptone water to each sample. These solutions were then placed in Erlenmeyer and incubated at $37^{\circ}$ $\mathrm{C}$ for 24 hours. Aliquots from pre-enrichment were inoculated into selective enrichment liquid media at a ratio of $1 / 100$ in Rappaport-Vassiliadis broth and at 1/10 in Selenite-Cysteine broth. A loopful of each broth was streaked on plates of Brilliant Green agar, MacConkey agar, and Salmonella-Shigella agar. The temperature and the period of incubation were standardized at $37^{\circ} \mathrm{C}$ for 24 hours. Two to three suspected colonies of Salmonella from each plate were collected for presumptive biochemical identification with Triple Sugar Iron (TSI); Lysine-Iron agar (LIA); Sulfur Indol Motility agar (SIM), and Citrate agar, incubated at the same time and temperature.

Companies and categories of carcasses were compared using the Chi-square $\left(x^{2}\right)$ non-parametric test for qualitative analysis at a probability of $5 \%(p<0.05)$.

\section{RESULTS}

The results showed the presence of enterobacteria in all broiler carcasses categories commercialized in Metropolitan Region of Fortaleza. As for theidentified bacteria, there were qualitative variations, as we can see on Table 1.

The biochemical presumptive identification showed the following enterobacteria isolation in broiler carcasses: Proteus sp. (66.7\%), Enterobacter sp. (15.7\%), Citrobacter sp. (2\%), Escherichia coli (47.1\%), Klebsiella sp.(11.8\%), Shigella sp.(5.9\%) and Salmonella sp. $(11.8 \%)$.

Fresh carcasses showed higher contamination levels compared to refrigerated and frozen ones. This difference was significant in cases of Proteus contamination. Regarding E. coli, there was no significant difference between the refrigerated and fresh carcasses, differing from the frozen ones $(\mathrm{p}<$ $0.05)$, classified as the lowest contamination level (Table 1).

Regarding the Salmonella isolation, a greater presence of this genus was verified in refrigerated carcasses. Frozen carcasses presented the lowest contamination levels for Salmonella. GenusCitrobacter was isolated only from frozen carcasses. 
Table 1 - Enterobacteria species isolated, according to their origin, from broiler carcasses commercialized in the Metropolitan Region of Fortaleza, Ceara, Brazil.

\begin{tabular}{|c|c|c|c|c|c|c|c|c|}
\hline \multirow{2}{*}{$\begin{array}{l}\text { Samples } \\
\text { Bacteria }\end{array}$} & \multirow[t]{2}{*}{$\begin{array}{l}\text { Fresh } \\
\mathrm{n}=14\end{array}$} & & \multicolumn{2}{|c|}{$\begin{array}{l}\text { Refrigerated } \\
\mathrm{n}=18\end{array}$} & \multirow[t]{2}{*}{$\begin{array}{l}\text { Frozen } \\
\mathrm{n}=19\end{array}$} & \multicolumn{3}{|c|}{$\begin{array}{l}\text { Total } \\
n=51\end{array}$} \\
\hline & & $(\%)$ & & $(\%)$ & & $(\%)$ & & $(\%)$ \\
\hline Proteus sp. & $13^{\mathrm{a}}$ & $(92.8)$ & $11^{b}$ & $(61.1)$ & $10^{\mathrm{b}}$ & $(52.6)$ & $34 / 51$ & $(66.7)$ \\
\hline Enterobacter sp. & $4^{\mathrm{a}}$ & $(28.6)$ & $2^{a}$ & $(11.1)$ & $2^{a}$ & $(10.5)$ & $8 / 51$ & $(15.7)$ \\
\hline Citrobacter sp. & $0^{a}$ & $(0)$ & $0^{\mathrm{a}}$ & $(0)$ & $1^{\mathrm{a}}$ & (5.3) & $1 / 51$ & (2) \\
\hline Escherichia coli. & $10^{\mathrm{b}}$ & $(71.4)$ & $9 a \mathrm{~b}$ & $(50)$ & $5^{a}$ & $(26.3)$ & $24 / 51$ & $(47.1)$ \\
\hline Klebsiella sp. & $0^{\mathrm{a}}$ & $(0)$ & $3^{a}$ & $(16.7)$ & $3^{\mathrm{a}}$ & (15.8) & $6 / 51$ & (11.8) \\
\hline Shigella sp. & $2^{a}$ & $(14.3)$ & $1^{\mathrm{a}}$ & (5.5) & $0^{\mathrm{a}}$ & $(0)$ & $3 / 51$ & (5.9) \\
\hline Salmonella sp. & $2^{a}$ & (14.3) & $3^{a}$ & $(16.7)$ & $1^{\mathrm{a}}$ & (5.3) & $6 / 51$ & $(11.8)$ \\
\hline
\end{tabular}

$a, b$ - the different letters mean the existence of significant difference among the values $(p<0.05)$.

n- number of isolated samples

Table 2 - Number of enterobacteria isolated in different culture media combinations, from broiler carcasses commercialized in the Metropolitan Region of Fortaleza, Ceara, Brazil.

\begin{tabular}{|c|c|c|c|c|c|c|c|}
\hline \multirow[t]{2}{*}{ Bacteria } & \multicolumn{6}{|c|}{ Culture media } & \multirow{2}{*}{$\begin{array}{l}\text { Positive } \\
\text { Carcass } \\
\text { Samples }\end{array}$} \\
\hline & $\mathrm{RB}$ & SB & RM & SM & RS & SS & \\
\hline Proteus sp. & $3^{a}$ & $6^{\mathrm{ab}}$ & $13^{\mathrm{bc}}$ & $28^{\mathrm{d}}$ & $11^{\mathrm{b}}$ & $20^{c}$ & 34 \\
\hline Enterobacter sp. & $0^{\mathrm{a}}$ & $0^{\mathrm{a}}$ & $5^{b}$ & $5^{b}$ & $0^{\mathrm{a}}$ & $2^{a b}$ & 8 \\
\hline Citrobacter sp. & $0^{\mathrm{a}}$ & $0^{\mathrm{a}}$ & $1^{\mathrm{a}}$ & $1^{\mathrm{a}}$ & $1^{\mathrm{a}}$ & $0^{\text {a }}$ & 1 \\
\hline Escherichia coli & $6^{a}$ & $10^{\mathrm{ab}}$ & $19^{c}$ & $9^{a}$ & $16^{\mathrm{bc}}$ & $5^{a}$ & 24 \\
\hline Klebsiella sp. & $0^{a}$ & $0^{\mathrm{a}}$ & $3^{b}$ & $0^{\text {a }}$ & $2^{\mathrm{ab}}$ & $3^{b}$ & 6 \\
\hline Shigella sp. & $0^{\mathrm{a}}$ & $0^{\mathrm{a}}$ & $0^{\mathrm{a}}$ & $1^{\mathrm{ab}}$ & $2^{\mathrm{ab}}$ & $3^{b}$ & 3 \\
\hline Salmonella sp. & $3^{b}$ & $3^{\mathrm{b}}$ & $1^{\mathrm{ab}}$ & $0^{\text {a }}$ & $0^{\mathrm{a}}$ & $1^{\mathrm{ab}}$ & 6 \\
\hline Total & $9^{a}$ & $16^{\mathrm{a}}$ & $41^{\mathrm{bc}}$ & $44^{c}$ & $32^{\mathrm{b}}$ & $31^{b}$ & 82 \\
\hline
\end{tabular}

$a, b, c, d-$ The different letters mean the existence of significant difference among the values $(p<0,05)$.

RB- Rappaport-Vassiliadis Broth + Brilhant Green Agar

SB- Selenite-Cystine Broth + Brilhant Green Agar

RM-Rappaport-Vassiliadis Broth + MacConkey Agar

SM- Selenite-Cystine Broth + MacConkey Agar

RS- Rappaport-Vassiliadis Broth + Salmonella-Shigella Agar

SS- Selenite-Cystine Broth + Salmonella-Shigella Agar

The media SM, followed by the SS, were superior $(\mathrm{p}<0.05)$, considering the growth of Proteus spp., and were the worst to the other genus except for Salmonella spp., as would be expected. The higher number of enterobacteria isolates was obtained in the SM, followed by the RM and the SS media.

\section{DISCUSSION}

Contamination of poultry products by enterobacteriais one of the greatest problems regarding world food industry, and animal feces are their main contaminating source (RASMUSSEN et al., 2004). OLIVEIRA et al. (2004) verified the following frequency of enterobacteria in broiler feces: Proteus sp., 86.7\%, Arizona sp., 6.7\%, Enterobacter sp., 66.7\%, Citrobacter sp.,6.7\%, Edwardsiellasp.,3.3\%, E. coli, 60\%, Klebsiella sp., $6.7 \%$ and Shigella sp. $13.3 \%$.

The role of Proteus spp in foodborne diseases is a controversy, despite its potential as a pathogen. According to Franco; LANDGRAF (1996), Proteus spp is related with food deterioration and its presence is not directly related to infections, but as a contaminant 
agent. It is involved in the decomposition of carcasses and can be found in feces, sewer water, putrefied meat, suppurating wounds, among others (BIER, 1981). HobBs, RoBerTs (1999) reported that this bacteria is related to intoxication of scombroid fishes, making humans susceptible, presenting symptoms as: nausea, vomiting, peri-ophthalmic swelling, cyanotic tongue and gum, itching, headache and respiratory problems.

Proteus spp. and Escherichia were the genus with the highest number of isolations in all carcass categories. YogARATNAM, (1995) reported that in 43\% of broiler carcasses condemned for disease at processing plants had lesions consistent with colisepticemia. The chickens are susceptible to colonization by E. coli O157:H7, an important shiga toxin-producing, enterohemorrhagic pathogen of humans, but low occurrence of natural infection has been found in both chickens and turkeys in different geographic areas (Guo et al., 1998; HeuvelinK et al., 1999).

In the present study, the lowest level of contamination was found for Citrobacter spp. IvERSEN; FORSYTHE (2004) isolated 49 samples from food destined to children. Out of all, 6 were contaminated with the genus Enterobacter, three with Escherichia spp. and none with Citrobacter spp and Klebsiella spp. In the same study, one isolate of Citrobacter spp, Serratiaspp and Klebsiella spp, three of Enterobacter spp and none of Escherichia spp were detected in 82 samples of milk prepared for children's consumption.

Species of Enterobacter have been associated with rare cases of infantile meningitis, newborn death and bacteremia. This genus has been often isolated from food, such as: meat, cheese, vegetables and condiments (LAI, 2001; IVERSEN; ForSYTHE, 2003).

Bacteria of the genus Shigella were, in the present study, isolated from four samples. They are responsible for the shigellosis or bacillary dysentery, involving invasion and destruction of the epithelial layer of the mucosa causing intense inflammatory reaction(CAMPOS, 2002).

Shigella infections remain a global public health concern, causing diarrhea in both the developing and developed regions (GUERRANT etal., 1990). The bacteria are readily transmitted through the fecal-oral route, with the majority of illnesses arising through the consumption of fecally contaminated food and water. Poor personal hygiene and sanitation are the common sources of such food and water contaminations (SAPSFORD et al., 2004). MEAD et al. (1999) estimated that $20 \%$ of the total number of cases of shigellosis involve food as the vehicle of transmission. The food involved was contaminated during handling by infected workers (BRYAN, 1978).

Centers For Disease Control And Prevention (1999) estimates that the number of humans cases for Shigella and Salmonella is, annually, 89.648 and 1.341.873, with 1.246 and 15.608 hospitalizations and 14 and 553 deaths, respectively. The selective enrichment is an essential step, because inhibits the competitive microbiota, favoring growth of Salmonella (BuSSE, 1995; RHODES et al., 1985).

Selenite-Cystine broth and MacConkey agar combination showed the best results, due to two factors: the aminoacid cystine establishes oxidereduction potential that favors the enrichment and recovery of the enterobacteria in scarce number and the MacConkey agar has, in its composition, biliar salts that inhibit the growth of Gram-positive bacteria. According to Michael et al. (2003), the RappaportVassiliadis broth, as a selective enrichment, is superior to Selenite-Cystine in order to obtain Salmonella isolation.

Usage of different culture media combinations is better than using a single medium because there are a number of factors that can affect the bacterial isolation, choosing many different culture media is an essential requirement for isolation of any microorganisms (AlBUQUERQUE et al., 2000).

It was verified a significant occurrence of enterobacteria, including human pathogens, in broiler carcasses in Ceara State. The fresh carcasses samples were more contaminated than the refrigerated and frozen ones. We also observed that no combination of culture media was able to detect all enterobacteria contamination in broiler carcasses. Thus, it may be necessary the use of several combinations of culture media to determine the real microbiological quality of broiler carcasses.

\section{REFERENCES}

Abu-Ruwaida, A.S.; Sawaya, W.N.; Dashti, B.H.; Murad, M.; AL-OthMAN, H.A. Microbiological quality of broilers during processing in a modern commercial slaughterhouse in Kuwait. Journal Food Protection, v.57, p.887-892, 1994.

Albuquerque, R.; De Ito, N.M.K.; MiyajI, C.I. Comparative study to different culture media for Salmonella recovery in feedstuffs and feeds. Brazilian Journal of Veterinary Research and Animal Science, v.37, n.1, 2000. Disponível em: $<$ http://www.scielo.br/scielo. php ? s c ript $=00 \mathrm{sci}_{-}$arttext\&pid=S1413$95962000000100012 \& \operatorname{lng}=$ en\&nrm $=$ iso $>$. Acesso em: 3 out. 2006.

BIER, O. Bactérias intestinais. In: BIER, O. (Ed.). Bacteriologia e imunologia. 21.ed. São Paulo: Melhoramentos, 1981. 517-531p.

BRYAN, F.L. Factors that contribute to outbreaks of foodborne disease. Journal of Food Protection, v.41, p.816, 1978.

Busse, M. Media for Salmonella. International Journal of Food Microbiology, v.26, p. 117-131, 1995. 
BuzBy, J.C. Older adults at risk of complications from microbial foodborne illness. Food Review, v.25, n.2, p.30-36, 2002

Campos, L.C. Shigella. In Trabulsi, L.R.; Alterthum, F.; Gompertz, O.F.; Candeias J.A.N. (Eds). Microbiologia. 3.ed. São Paulo: Atheneu, 2002. p. 235-238.

Centers For Disease Control AndPrevention, CDC/USDA/ FDA Foodborne Disease Active Surveillance Network, CDC's Emerging Infection Program. Annual report, 1999. Disponível em: < www.cdc.gov. foodnet/annual/1999/pdf/99_annual_pdf.htm>. Acesso em: 20 dez. 2001.

Cox,N.A.;M ercuri,A.J.;T ANNER, D.A.; Carson, M.O.; ThOMSON, J.E.; B AILEY, J.S. Effectiveness of sampling methods for Salmonella detection on processed broilers. Journal Food Protection, v.41, p.341-343, 1978.

Fitzgerald, M.; Bonner, C.; F oley, B.; W all, P.G. Analysis of outbreaks of infectious intestinal disease in Ireland: 1998 and 1999. Irish Medical Journal, v.94, p.140-144, 2001.

Franco, B.D.G.M.; LANDGRAF, M. Microbiologia dos alimentos. 2.ed. São Paulo: Atheneu, 1996. 182p.

Guerrant, R.L; Hughes, J.M.; Lima, N.L.; Crane, J. Diarrhea in developed and developing countries: magnitude, special settings, and etiologies. Reviews of Infectious Diseases, v.12, p.41-50, 1990. Supplement 1.

Guo, W.; Ling, C.; Cheng, F.; Guo, W.Z.; Ling, C.S.; Cheng, F.H. Preliminary investigation on enterohaemorrhagic Escherichia coli O157 from domestic animals and fowl in Fujian province. Chinese Journal of Zoonoses, v.14, p.3-6, 1998.

Heuvelink, A.E.;Zwartkruis-Nahuis,J.T.;V an Den Biggelaar, F.L.; VAN LeEuwen, W.J.; DE BOER, E. Isolation and characterization of verocytotoxin-producing Escherichia coli $\mathrm{O} 157$ from slaughter pigs and poultry. International Journal of Food Microbiology, v.52, p.67-75, 1999.

Hobbs, B.C.; RoberTs, D. Toxinfecções e controle higiênicosanitário de alimentos. São Paulo: Livraria Varela, 1999. 376p.

IVERSEN, C.; FORSYTHE, S.J.Risk profile of Enterobactersakazakii, an emergent pathogen associated with infant milk formula. Trends in Food Science \& Technology, v.14, p.443-454, 2003.

IVERSEN, C.; FoRSYTHE, S.J. Isolation of Enterobacter sakazakii and other Enterobacteriaceae from powdered infant formula milk and related products. FoodMicrobiology, v.21, p.771-777, 2004.

LAI, K.K. Enterobacter sakazakii infections among neonates, infants, children, and adults: case reports and a review of the literature. MedicineBaltimore, v.80, p.113-122,2001.

Mead, P.S.; Slutsker, L.; Dietz, V.; Mccaig, L.F.; Bresee, J.S.; Shapiro, C.; Griffin P.M.; TAuxe, R.V. Food-related illness and death in the United States. Emerging Infectious Disease, v.5, p.607-625, 1999.
Meng, J.; Doyle, M.P. Emerging and evolving microbial foodborne pathogens. Bulletin de L'Institute Pasteur, v.96, p.151-164, 1998.

Michael, G.B.; Smoneti, R.; Costa, M.; Cardoso, M Comparison of different selective enrichment steps to isolate Salmonella sp. from feces of finishing swine. Brazilian Journal of Microbiology, v.34, p.138-142, 2003.

NADVORNY, A.; FigueIREdo,D.M.S.;S chmidT, V. Ocorrência de Salmonella sp. em surtos de doenças transmitidas por alimentos no Rio Grande doSul em 2000. ActaScientiae Veterinariae, v.32, p.47-51, 2004.

OliveIRa, W.F.; C ARDOSO, W.M.;M ARQUES, L.C.L.;S ALlES, R.P.R.; Aguiar-Filho, J.L.C.; TeixeIRA, R.S.C.; RomÃo, J.M.; Lima, A.C.P. Use of differentculture media to enterobacteria isolation in feces samples from industrial broiler flocks in Ceara State, Brazil. Revista Portuguesa de Ciencias Veterinarias, v.99, n.552, p.211-214, 2004.

Rasmussen, M.A.; CAsey, T.; Petrich, J.W. Meat carcass inspection using the fluorescence of dietary porphyrins. In: JOINT ANNUAL MEETING OF THE AMERICAN DAIRY SCIENCE ASSOCIATION, 2004, St Louis Abstract. St Louis: American Society of AnimalScience, Poultry Science Association, 2004. p.166.

Rhodes, P.; Quesnel, L.B.; Collard, P. Growth kinetics of mixed culture in Salmonella enrichment media.Journal Applied Bacteriology, v.59, p.231-237, 1985.

Roberts, D.; Hooper, W.; Greenwood, M. Isolation and enrichment of microorganisms. In: ROBERTS, D. (Ed.). Practical food microbiology. 2.ed. London: Public Health Laboratory Service, 1995. p.130-142.

RusselL, S.M.; WALKER, J.M. The effect of evisceration on visible contamination and the microbiological profile of fresh broiler chicken carcasses using the Nu-Tech evisceration system or the conventional streamlined inspection system. Poultry Science, v.76, p.780-784, 1997.

SAPSFORD, K.E.; RASOOLY, A.; TAITT, C.R.; LigleR, F.S. Detection of Campylobacter and Shigella species in food samples using an array biosensor. Analytical Chemistry, v.76, p.433-440, 2004.

Trabulsi, L.R.; Campos, L.C. Generalidades sobre Enterobactérias. In: Trabulsi L.R., Alterthum F., Gompertz O.F., E CANDEIAS J.A.N. (Eds). Microbiologia. 3.ed. São Paulo: Atheneu, 2002. p.207-213.

VieIra, R.H.S.F.; Catter, K.M.; SAKer-SAMPaio, S.; Rodrigues, D.P.; TheOPHILO, G.N.D. The stormwater drain system as a pollution vector of the seashore in Fortaleza (Ceara State, Brazil). Brazilian Journal of Microbiology, v.33, p.294-298, 2002.

Yogaratnam, V. Analysis of the causes of high rates of carcass rejection at a poultry processing plant. Veterinary Record, v.137, p.215-217, 1995.

Received on 3/7/06

Accepted on 11/10/06 